\title{
An Evaluation of Artificial Fish Nest for Assessment Enhancement Effects of Fishery Resources of in Xiangjiang River
}

\author{
Ying Xia, Qiang Hu, Xiping Yuan* \\ Dongting Lake Finless Porpoise Conservation Center of Yueyang, Yueyang, China \\ Email: *kerryuan@163.com
}

How to cite this paper: Xia, Y., Hu, Q., \& Yuan, X. P. (2020). An Evaluation of Artificial Fish Nest for Assessment Enhancement Effects of Fishery Resources of in Xiangjiang River. Journal of Geoscience and Environment Protection, 8, 15-19.

https://doi.org/10.4236/gep.2020.86002

Received: May 8, 2020

Accepted: June 13, 202

Published: June 16, 2020

Copyright ( 2020 by author(s) and Scientific Research Publishing Inc. This work is licensed under the Creative Commons Attribution International License (CC BY 4.0).

http://creativecommons.org/licenses/by/4.0/

\begin{abstract}
Artificial fish nests are set in Lukou section and Hengyang section of Xiangjiang River from March 20 to May 10, 2019. The structure of artificial fish nest is bamboo frame, with the size of $2.5 \mathrm{~m} \times 5.0 \mathrm{~m} \times 4$ and a unit frame area of $60 \mathrm{~m}^{2}$. A total of 58,201 eggs were collected by 24 monitoring times, of which 30,441 were from Lukou and 27,760 from Hengyang. 3831 fish eggs identify 8 fish species using morphological or molecular biological methods. The results showed that the number of eggs peaked from the $8^{\text {th }}$ day to the $24^{\text {th }}$ day after the nest entered the water, and then decreased rapidly. There was significant negative correlation between egg number in per $\mathrm{m}^{2}$ fish nest and days of fish nest $(P<0.01)$. The economic benefits of artificial fish nests were RMB 11.81 million. The artificial fish nest can not only increase the population of fish, but also has significant economic benefits.
\end{abstract}

\section{Keywords}

Artificial Fish Nest, Enhancement Effects of Fishery Resources, Xiangjiang River

\section{Introduction}

With the rapid development of the society, water conservancy and hydropower projects, dredging and shipping, environmental pollution has more and more significant impact on the water environment (Xie, 2017), leading to the gradual depletion of aquatic biological resources. It has become an urgent and important task to carry out artificial fish proliferation and environmental restoration (Luo et al., 2011; Liao et al., 2002; Liao et al., 2016). The artificial fish nest can provide a bed for the production of slimy eggs, which is a convenient, economic and ef- 
fective way of artificial proliferation (Becker \& Suthers, 2014; Nagayama \& Nakamura, 2010; Li et al., 2018). In this study, evaluation of artificial fish nest for assessment enhancement effects of fishery resources in Xiangjiang River.

\section{Materials and Methods}

\subsection{Study Area and Time}

Artificial fish nests are set in Lukou section and Hengyang section of Xiangjiang River from March 20 to May 10, 2019 (Table 1). The setting area has the following characteristics: the water level is deep, the water flow is less than $0.2 \mathrm{~m} / \mathrm{s}$, and there is water grass growing along the coast, which leads to the lack of spawning place for the sticky egg fish.

\subsection{Structure and Setting Mode of Artificial Fish Nest}

The structure of artificial fish nest is bamboo frame (Figure 1), with the size of $2.5 \mathrm{~m} \times 5.0 \mathrm{~m} \times 4$ and a unit frame area of $60 \mathrm{~m}^{2}$. The buoyancy is adjusted by Gabions and floats to make the surface fish nests float on the water. The edge of the bamboo frame is tied with a cable, and the other end of the cable is tied with an anchor stone. The spacing between fixing rods is $40 \mathrm{~cm} .3-5$ pieces brown pieces were binded on the fixed rod every $30 \mathrm{~cm}$ (Liao et al., 2015).

\subsection{Sampling Methods Data Analyses}

Since the setting of artificial fish nest, each unit shall be inspected, maintained, observed, recorded and sampled at 8:00 a.m. every fourth day. A $10 \mathrm{~cm} \times 10 \mathrm{~cm}$

Table 1. Location, time and area of artificial fish nest in Xiangjiang River in 2019.

\begin{tabular}{cccc}
\hline Setting location & Latitude and longitude & Time & Area $\left(\mathbf{m}^{2}\right)$ \\
\hline Lukou & E113.138995; N27.588719 & March 20 to May 10 & 4200 \\
Hengyang & E112.620019; N26.889092 & March 20 to May 10 & 5600 \\
Total & & & 9800
\end{tabular}

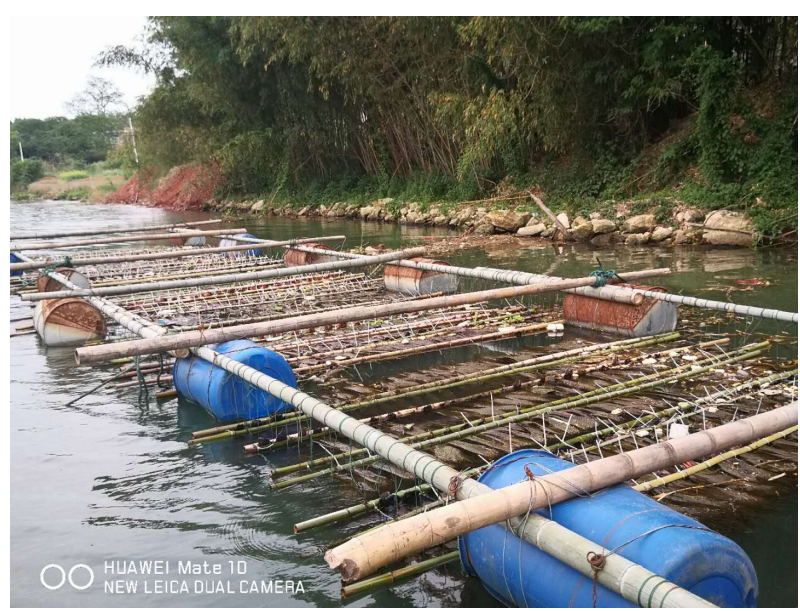

Figure 1. Photograph of artificial fish nest, taken on 10 March 2019. 
square floating frame is used to randomly cast and select samples in the fish nest area. Six samples are selected for six units to calculate the spawning amount and fertilization rate per unit area. According to the different developmental stages, the production batches were separated and the species of eggs were identified by morphological or molecular biological methods.

\section{Results}

A total of 58,201 eggs were collected by 24 monitoring times, of which 30,441 were from Lukou and 27,760 from Hengyang (Table 2). The average number of fish eggs collected in Lukou and in Hengyang was 3636 eggs and 3521 eggs, separately.

3831 fish eggs identify 8 fish species using morphological or molecular biological methods (Figure 2). The top three percentages of catches are Carassius auratus (46.4\%), Cyprinus carpio (33.8\%), and Hemicculter Leuciclus (8.1\%).

The results showed that the number of eggs peaked from the $8^{\text {th }}$ day to the $24^{\text {th }}$ day after the nest entered the water, and then decreased rapidly (Figure 3). There was significant negative correlation between egg number in per $\mathrm{m}^{2}$ fish nest and days of fish nest $(P<0.01)$. According to Calculation method for economic

Table 2. Statistics of eggs adhered to artificial nests.

\begin{tabular}{|c|c|c|c|c|c|c|c|c|c|c|c|c|c|c|}
\hline Days of fishe nest in water & & 4 & 8 & 12 & 16 & 20 & 24 & 28 & 32 & 36 & 40 & 44 & 48 & Total \\
\hline \multirow[t]{3}{*}{ Number of sample (eggs) } & Lukou & 0 & 22 & 4408 & 16,833 & 7810 & 649 & 308 & 210 & 133 & 55 & 9 & 4 & 30,441 \\
\hline & Hengyang & 0 & 30 & 9040 & 11,509 & 5611 & 255 & 260 & 586 & 241 & 217 & 7 & 4 & 27,760 \\
\hline & Total & & & & & & & & & & & & & 58,201 \\
\hline \multirow[t]{2}{*}{ Average density (eggs/m²) } & Lukou & 0 & 92 & 18367 & 70,138 & 32,542 & 2704 & 1283 & 875 & 554 & 229 & 38 & 17 & 126,838 \\
\hline & Hengyang & 0 & 125 & 37667 & 47,954 & 23,379 & 1063 & 1083 & 2442 & 1004 & 904 & 29 & 17 & 115,667 \\
\hline \multirow{2}{*}{$\begin{array}{l}\text { Increase the quantity of fishery } \\
\text { resources }\left(10^{4} \text { eggs }\right)\end{array}$} & Lukou & 0 & 39 & 7714 & 29,458 & 13,668 & 1136 & 539 & 368 & 233 & 96 & 16 & 7 & 53,272 \\
\hline & Hengyang & 0 & 70 & 21,093 & 26,854 & 13,092 & 595 & 607 & 1367 & 562 & 506 & 16 & 9 & 64,773 \\
\hline
\end{tabular}

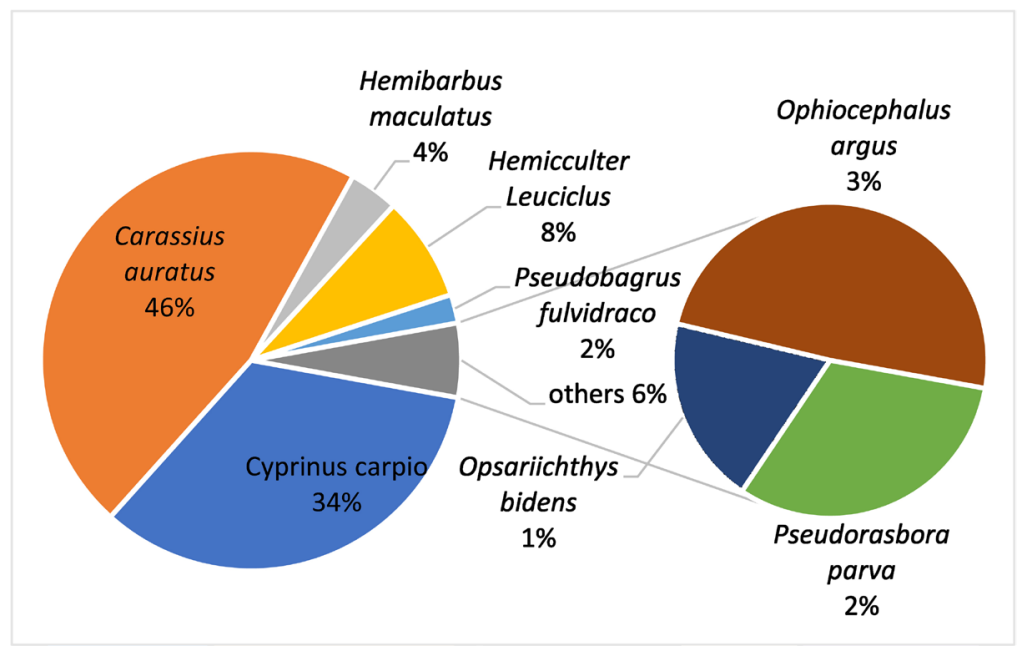

Figure 2. The percentages of catches. 


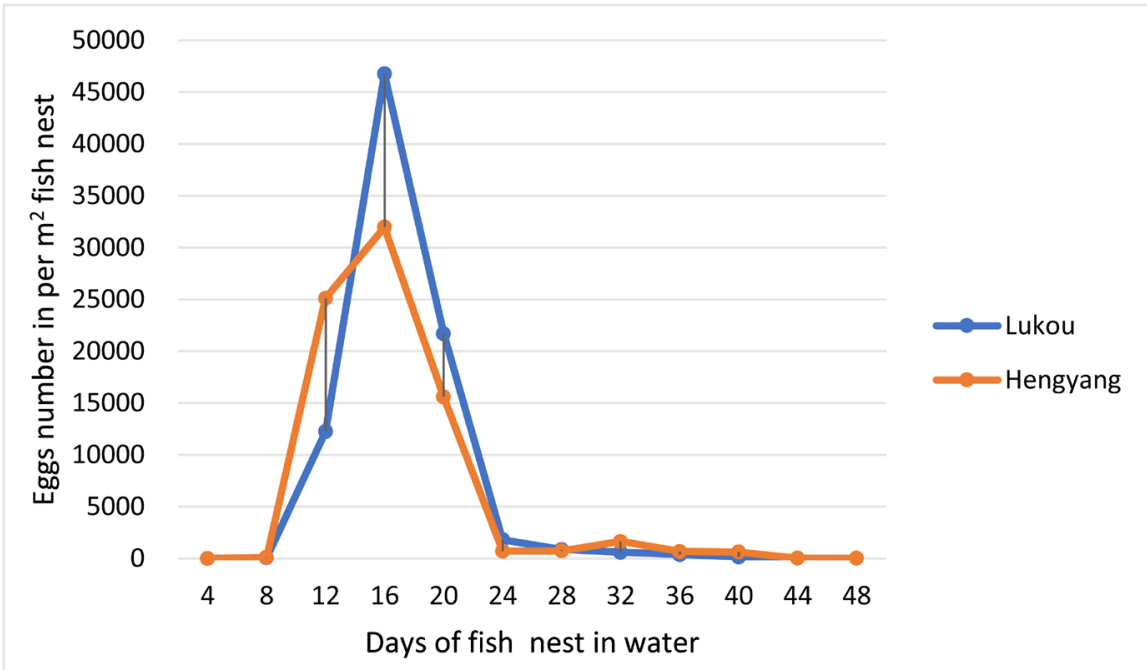

Figure 3. Correlation between eggs number in per $\mathrm{m}^{2}$ fish nest and days of fish nest in water.

loss of fishery pollution accidents (Chen et al., 2018), we analyze that the economic benefits of artificial fish nests were RMB 11.81 million. Input output ratio is 8.6 .

\section{Discussion}

Eight species of fish, such as carp and crucian carp, have been bred; the quantity was $118,045 \times 10^{4}$ eggs, by setting artificial fish nests in Xiangjiang River. Artificial artificial fish nest has the following advantages to breed the original resources of the river section; the parent background is clear, and the original state of population genes is preserved. Thus, the risk of artificial propagation and release is avoided. For example, the parental source of multiplying and releasing fish may be uncertain, which will lead to the germplasm resources degradation (Jiang \& He, 2008).

The spawning period of stickiness is generally from March to May. In order to ensure the spawning effect of artificial fish nests, they should be cleaned regularly (Zhou et al., 2019; Wang et al., 2018). The results showed that the number of eggs peaked from the $8^{\text {th }}$ day to the $24^{\text {th }}$ day after the nest entered the water, and then decreased rapidly. In order to reduce the management cost, we suggest that the artificial fish nest should be set from March 20 to the end of April.

We analyze that the economic benefits of artificial fish nests were RMB 11.81 million. Input-output ratio is 8.6. More than 2000 artificial fish nests were put into Xijiang River (Peng et al., 2016), which can increase the economic benefits of fishing by 12.00 million yuan. The artificial fish nest can not only increase the population of fish, but also has significant economic benefits. It is suggested that the restoration of degraded fish habitat is a long-term task, which needs effective financial investment and technical support. However, cultural and statistical factors restrict its development. There is still a large space for the research and 
application of artificial fish nests.

\section{Conflicts of Interest}

The authors declare no conflicts of interest regarding the publication of this paper.

\section{References}

Becker, A., \& Suthers, I. M. (2014). Predator Driven Diel Variation in Abundance and Behaviour of Fish in Deep and Shallow Habitats of an Estuary. Estuarine, Coastal and Shelf Science, 144, 82-88. https://doi.org/10.1016/j.ecss.2014.04.012

Chen, B. J., Qu, K. M., \& Chen, J. F. (2018). Calculation Method for Economic Loss of Fishery Pollution Accidents. National Standard of the People's Republic of China, GB/T 21678-2018.

Jiang, G. F., \& He, X. F. (2008). A Survey of Fish Resources in the Lower Reaches of Jialing River. Freshwater Fisheries, 38, 3-7.

Li, Y. T., Guo, M. Y., Zhan, C. et al. (2018). The Enhancement Effects of Fishery Resources on Artificial Fish Nest: A Review. Freshwater Fisheries, 48, 58-62.

Liao, F. C., He, W., Huang, X. R. et al. (2002). Current Status and Changes of Fishery in Dongting Lake. Journal of Hydrobiology, 26, 623-627.

Liao, F. C., He, X. C., He, W. et al. (2016). Current Status and Protection Strategies of Fishery Resources and Ecological Environment in Dongting Lake. Journal of Yueyang Vocational and Technical College, 21, 32-37.

Liao, F. C., Tang, J. S., Yuan, X. P. et al. (2015). The Enhancement Effects of Fishery Resources on Artificial Fish Nest. Local Standards of Hunan Province: DB43/T1077-2015.

Luo, X. Y., Li, F., \& Zhang, J. (2011). Status of Water Co-Environment in Yangtze River Basin and Countermeasures for Its Protection and Restoration. Yangtze River, 42, 45-47.

Nagayama, S., \& Nakamura, F. (2010). Fish Habitat Rehabilitation Using Wood in the World. Landscape and Ecological Engineering, 6, 289-305. https://doi.org/10.1007/s11355-009-0092-5

Peng, P., Li, Y. F., \& Li, X. H. (2016). Evaluation of the Effect of Xijiang Artificial Fish Nest on Carp Breeding. Freshwater Fisheries, 46, 45-49.

Wang, J. H., Jiang, W., Gao, Y. et al. (2018). Use of Artificial Fish Nests and Incubators in Three Georges Reservoir to Conserve Fish Species with Adhesive Eggs. Journal of Hydroecology, 39, 116-120.

Xie, P. (2017). Biodiversity Crisis in the Yangtze River: The Culprit Was Dams, Followed by Overfishing. Journal of Lake Science, 29, 1279-1299. https://doi.org/10.18307/2017.0601

Zhou, L., Guo, D., Zeng, L. et al. (2019). The Structuring Role of Artificial Structure on Fish Assemblages in a Dammed River of the Pearl River in China. Aquatic Living Resources, 31, Article No.: 15. https://doi.org/10.1051/alr/2018003 